\title{
Silver nanoparticles enhance the apoptotic potential of gemcitabine in human ovarian cancer cells: combination therapy for effective cancer treatment
}

This article was published in the following Dove Press journal:

International Journal of Nanomedicine

5 September 2017

Number of times this article has been viewed

\author{
Yu-Guo Yuan' \\ Qiu-Ling Peng ${ }^{2}$ \\ Sangiliyandi Gurunathan ${ }^{3}$ \\ 'College of Veterinary Medicine/ \\ Animal Science and Technology/ \\ Jiangsu Co-Innovation Center for \\ Prevention and Control of Important \\ Animal Infectious Diseases and \\ Zoonoses, Yangzhou University, \\ Yangzhou, Jiangsu, People's Republic \\ of China; ${ }^{2}$ College of Chemistry and \\ Bioengineering, Yichun University, \\ Yichun, Jiangxi, People's Republic of \\ China; ${ }^{3}$ Department of Stem cell and \\ Regenerative Biotechnology, Konkuk \\ University, Seoul, Republic of Korea
}

Correspondence: Yu-Guo Yuan College of Veterinary Medicine, Yangzhou University, Wenhui Road \#48, Yangzhou, Jiangsu 225009,

People's Republic of China

Tel +86 87979228

Fax +8651487972218

Emailyyg9776430@163.com

Sangiliyandi Gurunathan Department of Stem Cell and Regenerative Biotechnology, Konkuk University, 120 Neungdong-ro, Gwangjin-gu, Seoul I43-70I, Republic of Korea

Tel +82 2450058 I

Email gsangiliyandi@yahoo.com
Background: Gemcitabine (GEM) is widely used as an anticancer agent in several types of solid tumors. Silver nanoparticles (AgNPs) possess unique cytotoxic features and can induce apoptosis in a variety of cancer cells. In this study, we investigated whether the combination of GEM and AgNPs can exert synergistic cytotoxic effects in the human ovarian cancer cell line A2780.

Methods: We synthesized AgNPs using resveratrol as a reducing and stabilizing agent. The synthesized nanomaterials were characterized using various analytical techniques. The anticancer effects of a combined treatment with GEM and AgNPs were evaluated using a series of cellular assays. The expression of pro- and antiapoptotic genes was measured using real-time reverse transcription polymerase chain reaction. Apoptosis was confirmed by TUNEL assay.

Results: In this study, combined treatment with GEM and AgNPs significantly inhibited viability and proliferation in A2780 cells. Moreover, the levels of apoptosis in cells treated with a combination of GEM and AgNPs were significantly higher compared with those in cells treated with GEM or AgNPs alone. Our data suggest that GEM and AgNPs exhibit potent apoptotic activity in human ovarian cancer cells. Combined treatment with GEM and AgNPs showed a significantly higher cytotoxic effect in ovarian cancer cells compared with that induced by either of these agents alone.

Conclusion: Our study demonstrated that the interaction between GEM and AgNPs was cytotoxic in ovarian cancer cells. Combined treatment with GEM and AgNPs caused increased cytotoxicity and apoptosis in A2780 cells. This treatment may have therapeutic potential as targeted therapy for the treatment of ovarian cancer. To our knowledge, this study could provide evidence that AgNPs can enhance responsiveness to GEM in ovarian cancer cells and that AgNPs can potentially be used as chemosensitizing agents in ovarian cancer therapy.

Keywords: cell viability, proliferation, cytotoxicity, apoptosis, gemcitabine, silver nanoparticles

\section{Introduction}

Cancer is a group of diseases characterized by uncontrolled growth and spread of abnormal cells. Cancer is caused by external factors, such as tobacco use, infectious organisms, and unhealthy diet, as well as internal factors such as inherited genetic mutations and hormone and immune dysfunction. ${ }^{1,2}$ Cancer is a public health problem and leading cause of death worldwide. The International Agency for Research on Cancer reports ${ }^{3}$ that in 2012, 8.2 million deaths worldwide were caused by cancer, which will increase to up to 13 million by 2030. Deaths from cancer are increasing at an alarming rate in developed and developing countries. ${ }^{1,2,4}$ Epithelial ovarian 
carcinoma is the fifth most frequent cause of cancer in women and the leading cause of death from gynecological cancers. ${ }^{5}$ Cancers are managed using a variety of treatments including chemotherapy, hormone therapy, radiation, surgery, as well as immune and targeted therapy; however, there is still a high rate of relapse, drug resistance, and undesired side effects. ${ }^{1,2}$ Although various therapeutic modalities are available, new strategies for prevention, intervention, management, and treatment are urgently needed.

Gemcitabine (GEM) is a nucleoside analog that has been used for more than 15 years to treat a variety of cancers involving solid tumors such as breast, ovarian, and nonsmall-cell lung cancers. van Moorsel observed synergistic activity between gemcitabine and etoposide when A2780 cells were exposed to a combination of $\mathrm{dFdC}$ and etoposide for $24 \mathrm{~h}$. The combination of GEM and cisplatin inhibits angiogenic activity, and that of Akt kinase, in ovarian cancer cells. ${ }^{6}$ Although the development of novel cytotoxic drugs led to improved management of ovarian cancer during the past decade, eventually, more than $60 \%$ of patients with advanced cancer relapse, develop drug resistance, and die from progressive disease. ${ }^{7,8}$ Among therapeutic strategies, chemotherapy is effective against a number of cancers. ${ }^{9,10}$ However, platinum-based drugs exert anticancer effects by multiple mechanisms, which often leads to the development of chemoresistance and causes therapeutic failure. Currently, cancer therapy that relies on a single therapeutic treatment, such as chemotherapy, is of limited benefit to cancer patients. Combination therapy may be a promising strategy to improve therapeutic efficiency and eliminate undesired side effects. ${ }^{7}$ The combination of different drugs provides several advantages such as synergistic effects and reversal of drug resistance. ${ }^{7,11,12}$ Combined treatment with combretastatin and the apoptosis-inducing agent doxorubicin was more effective at suppressing the growth of melanoma and lung carcinoma than treatment with either of these agents alone. ${ }^{13}$ GEM is used extensively in combination with other chemotherapeutic drugs for the treatment of recurrent ovarian cancers and small cell lung cancers. ${ }^{14}$ Recent studies suggest that GEM is effective against ovarian cancer, and it was recently approved in several European countries for use in combination with carboplatin for the treatment of ovarian cancer. ${ }^{14}$ Although GEM can be combined with several chemotherapeutic agents, including cisplatin, pemetrexed, and taxanes, there are no data regarding the combination of GEM and silver nanoparticles (AgNPs). The major drawback of the GEM formulation is its high hydrobilicity and short-half life. To compensate those shortcomings such as high toxicity and severe side effects, here we selected a combination therapy model of
GEM with AgNPs. Previously, several studies have reported (including Arpicco et $\mathrm{al}^{15}$ ) the specificity of $\mathrm{C} 12 \mathrm{GEM}$ targeting toward CD44-overexpressing pancreatic adenocarcinoma cell line using hyaluronic acid-coated liposomes for active targeting of GEM. Thyroid-stimulating hormone nanoliposomes encapsulated with GEM showed improved anticancer efficacy in vitro and in a tumor model of follicular thyroid carcinoma. ${ }^{16}$ GEM-loaded PEG-AcPLA nanocapsules showed efficient and increased antitumor effect compared to the free drug on different cancer cell lines. Furthermore, in vivo studies exhibited significant anticancer activity of GEM-loaded PEG-AcPLA nanocapsules in two different xenograft murine models of human solid tumors. ${ }^{17}$

Recently, nanomedicine has enabled the design of personalized cancer treatments, which provides a solution to the main issue presented by current systemic therapeutic approaches. ${ }^{18}$ Using combinations of drugs and nanoparticles may be a synergistic approach that provides greater therapeutic effects than does single-drug treatment. Furthermore, targeting multiple signaling pathways may be a new model for cancer treatment. ${ }^{18}$ Combining various types of nanoparticles with different anticancer drugs is an advanced therapeutic strategy. Nanoparticle-mediated targeted therapy is an innovative and promising alternative that may be more effective than conventional small-molecule chemotherapeutics. Compared with classical, non-targeted drug combination modalities, nanoparticles are specifically targeted, which overcomes multiple drug resistance; they also provide enhanced therapeutic efficacy and show reduced adverse effects. ${ }^{19}$ Nanoparticle-based drug delivery allows the drugs to accumulate in tumors, by either passive or active targeting, without being eliminated by the body; this increases intracellular drug concentration and substantially enhances the cytotoxic effect of various antitumor agents. ${ }^{20}$

Nanoparticle-mediated combination therapy can be used with efflux pump inhibitors, proapoptotic compounds, and multiple drug resistance-targeted siRNA. ${ }^{18}$ AgNPs are potential cytotoxic agents in cancer cells and possess excellent antitumor potential. ${ }^{21}$ The antiangiogenic activity of AgNPs was demonstrated in bovine retinal endothelial cells. A 24-h treatment with biologically synthesized AgNPs at $500 \mathrm{nM}$ effectively inhibited cell viability, proliferation, and migration that had been previously induced with vascular endothelial growth factor. ${ }^{22,23}$ Biologically synthesized AgNPs show substantial cytotoxicity in human MDA-MB-231 breast cancer cells via a p53-dependent mechanism that involves activation of $\mathrm{p} 53$, $\mathrm{p}$-Erk1/2, and caspase-3 signaling, and downregulation of Bcl-2. ${ }^{24}$ AgNPs exert cytotoxicity by inducing oxidative stress ${ }^{25}$ and by utilizing the energy 
provided by glucose in the media. ${ }^{26}$ AgNPs can induce apoptosis, as well as autophagy, a critical cellular degradation process in various types of cancer cells. ${ }^{27}$ Inhibition of autophagy enhances the anticancer activity of AgNPs. ${ }^{28}$ Furthermore, AgNPs can inhibit cell viability and proliferation and can induce apoptosis in various cancer cell lines including breast, ovarian, lung, and cervical. ${ }^{24,29,30}$ The majority of in vitro studies use GEM in pancreatic cancer cells. Although the effects of GEM have been investigated in human ovarian cancer cells, the effects of using GEM combined with nanoparticles are still unexplored. Currently, there are no reports on the combined use of GEM and AgNPs in human ovarian cancer cells. Because AgNPs possess unique cytotoxic features, we selected AgNPs as the agent to use with GEM. To achieve effective combination therapy, we first synthesized and characterized AgNPs using resveratrol. Then, we evaluated the cytotoxic potential of GEM and AgNPs in human ovarian cancer cells. Finally, we investigated the mechanism of GEM- and AgNPs-induced apoptosis in human ovarian cancer cells.

\section{Materials and methods Materials}

Solutions of penicillin-streptomycin, trypsin-EDTA, Dulbecco's Modified Eagle's Medium (DMEM), Roswell Park Memorial Institute-1640, and 1\% antibiotic-antimycotic were obtained from Life Technologies/Gibco (Grand Island, NY, USA). Gemcitabine hydrochloride, fetal bovine serum (FBS), and the in vitro toxicology assay kit were purchased from Sigma-Aldrich Co. (St Louis, MO, USA). All other chemicals were purchased from Sigma-Aldrich Co., unless otherwise stated.

\section{Synthesis and characterization of AgNPs}

AgNPs were synthesized using resveratrol, according to a previously described method..$^{23}$ Briefly, $100 \mu \mathrm{M}$ resveratrol was mixed with $5 \mathrm{mM} \mathrm{AgNO}_{3}$ and incubated at $40^{\circ} \mathrm{C}$ for $6 \mathrm{~h}$. The bioreduction of silver ions was monitored spectrophotometrically at $420 \mathrm{~nm}$. Further characterization of the synthesized AgNPs was performed as described previously. ${ }^{23}$

\section{Cell viability assay}

Human ovarian cancer cells (A2780) were obtained from Sigma-Aldrich Co. The WST-8 assay was performed as described previously. ${ }^{30}$ Briefly, $2 \times 10^{5}$ cells were seeded in a 96-well plate and cultured in DMEM standard medium supplemented with $10 \% \mathrm{FBS}$ at $37^{\circ} \mathrm{C}$ under $5 \% \mathrm{CO}_{2}$. After $24 \mathrm{~h}$, the cells were washed twice with $100 \mu \mathrm{L}$ of serumfree DMEM and incubated for $24 \mathrm{~h}$ with $100 \mu \mathrm{L}$ of media containing GEM (25-200 nM) or AgNPs (25-200 nM). Cells not treated with GEM or AgNPs served as controls. After a 24-h incubation, the cells were washed twice with serumfree DMEM; then, $15 \mu \mathrm{L}$ of WST-8 solution was added to each well containing $100 \mu \mathrm{L}$ of serum-free DMEM. After a 1-h incubation at $37^{\circ} \mathrm{C}$ under $5 \% \mathrm{CO}_{2}, 80 \mu \mathrm{L}$ of the mixture was transferred to another 96-well plate. Absorbance was measured at $450 \mathrm{~nm}$ using a microplate reader.

\section{BrdU cell proliferation assay}

Cell proliferation was determined according to a previously described method ${ }^{31}$ and per manufacturer's instructions (Roche, Basel, Switzerland). Cells were incubated with AgNPs for $24 \mathrm{~h}$; the BrdU labeling solution was added to the culture medium $2 \mathrm{~h}$ before the end of the incubation. Cells were fixed and the level of incorporated BrdU was determined using the Cell Proliferation ELISA BrdU assay kit (Roche) following the manufacturer's instructions. Proliferation activity of the untreated cells at the time point of $0 \mathrm{~h}$ was considered as $100 \%$.

\section{Trypan blue exclusion assay}

The trypan blue exclusion assay was performed according to a previously described method. ${ }^{32,33}$ A2780 cells were plated in a 96-well plate and treated for $24 \mathrm{~h}$ with $50 \mathrm{nM}$ GEM, $50 \mathrm{nM}$ AgNPs, or a combination of $50 \mathrm{nM}$ GEM and $50 \mathrm{nM}$ AgNPs. After treatment, cells attached to the 96-well plate were washed once using phosphate-buffered saline (PBS, pH 7.4), trypsinized for 1 min with TrypLE ${ }^{\mathrm{TM}}$ (Thermo Fisher Scientific, Waltham, MA, USA, 12604-013) at $37^{\circ} \mathrm{C}$ in an incubator, and then neutralized with growth media supplemented with FBS. To determine live cells, the cells were stained using $4 \%$ trypan blue. Cell count was conducted manually using a hemocytometer.

\section{Cell morphology}

Ovarian cancer cells were plated in 6-well plates $\left(2 \times 10^{5}\right.$ cells per well) and incubated with $50 \mathrm{nM}$ GEM or $50 \mathrm{nM} \mathrm{AgNPs}$ for $24 \mathrm{~h}$. Cells cultured in media without the addition of GEM or AgNPs were used as controls. The morphology of the cells was examined at $24 \mathrm{~h}$ posttreatment with an OLYMPUS IX71 microscope (Tokyo, Japan) using the appropriate filters sets.

\section{Determination of Lactate Dehydrogenase}

The integrity of the cell membrane in human ovarian cancer cells was evaluated using the in vitro toxicology assay kit TOX7 (Sigma) according to the manufacturer's instructions and using a previously described method ${ }^{29}$ the kit measures the release of lactate dehydrogenase (LDH) from the cells. 
Briefly, the cells were exposed to concentrations of $50 \mathrm{nM}$ GEM, 50 nM AgNPs, or the combination of $50 \mathrm{nM}$ GEM and $50 \mathrm{nM}$ AgNPs for $24 \mathrm{~h}$, after which LDH was measured.

\section{Assessment of dead-cell protease activity}

Dead-cell protease activity was assessed using a previously described method. ${ }^{33}$ The cytotoxicity assay was used to evaluate cytotoxic effects of GEM and AgNPs in A2780 cells. Cytotoxicity was determined using the reaction of intracellular protease with a luminogenic peptide substrate (alanyl-alanylphenylalanyl-aminoluciferin). The degree of protease reaction measures the level of dead-cell protease activity in the dead cells. To exclude the background value of media color, we used $1 \%$ Triton X-100 as a control. To measure the luminescence used to determine the number of dead cells, $5 \mu \mathrm{L}$ of luminogenic peptide substrate was added to each well and allowed to incubate for $15 \mathrm{~min}$ at $37^{\circ} \mathrm{C}$. The luminescence was measured using a Luminescence Counter (Perkin Elmer, Waltham, MA, USA).

\section{Measurement of Reactive Oxygen Species}

The levels of reactive oxygen species (ROS) were estimated according to a method described previously. ${ }^{34}$ The cells were seeded onto 24 -well plates at a density of $5 \times 10^{4}$ cells per well and cultured for $24 \mathrm{~h}$. After washing twice with PBS, fresh media containing respective concentrations of $50 \mathrm{nM}$ GEM or $50 \mathrm{nM}$ AgNPs, or a combination of $50 \mathrm{nM}$ GEM and $50 \mathrm{nM}$ AgNPs, were added, and incubation was conducted for $24 \mathrm{~h}$. The cells were then supplemented with $20 \mu \mathrm{M} 2,7^{\prime}$ dichlorofluorescein diacetate (DCFH-DA), and incubation continued for $30 \mathrm{~min}$ at $37^{\circ} \mathrm{C}$. The cells were rinsed with PBS; then, $2 \mathrm{~mL}$ of PBS was added to each well, and the fluorescence intensity was determined using a spectrofluorometer (Gemini EM, Molecular Devices, Sunnyvale, CA, USA) with excitation at $485 \mathrm{~nm}$ and emission at $530 \mathrm{~nm}$.

\section{Mitochondrial membrane potential}

The cells were exposed to $50 \mathrm{nM}$ GEM, $50 \mathrm{nM}$ AgNPs, or a combination of $50 \mathrm{nM}$ GEM and $50 \mathrm{nM}$ AgNPs. Mitochondrial membrane potential (MMP) was then measured, as described previously, ${ }^{35}$ using a cationic fluorescent indicator JC-1 (Molecular Probes, Eugene, OR, USA). JC-1 is a lipophilic cation; in a reaction driven by $\Delta \Psi_{\mathrm{m}}$ in normal polarized mitochondria, JC-1 assembles into a red fluorescenceemitting dimer forming JC-1-aggregates. Cells were incubated with $10 \mu \mathrm{M} \mathrm{JC}-1$ at $37^{\circ} \mathrm{C}$ for $15 \mathrm{~min}$, washed with PBS, resuspended in PBS, and then the fluorescence intensity was measured. MMP was expressed as the ratio of the fluorescence intensity of the JC-1 aggregates to monomers.

\section{Extraction and amplification of mRNA}

Cells were treated with $50 \mathrm{nM}$ GEM, $50 \mathrm{nM}$ AgNPs, or a combination of $50 \mathrm{nM}$ GEM and $50 \mathrm{nM}$ AgNPs for $24 \mathrm{~h}$. Total RNA was extracted from the cells using the Arcturus picopure RNA isolation kit (EBioscience, Thermo Fisher Scientific), and samples were prepared according to the manufacturer's instructions. Real-time reverse transcriptase polymerase chain reaction (RT-PCR) was conducted using Vill7 (Applied Biosystems, Foster City, CA, USA) and SYBR Green as the double-stranded DNA-specific fluorescent dye (Applied Biosystems). The expression levels of target genes were normalized to the expression of $G A P D H$, which was used as housekeeping gene. The RT-PCR primer sets are shown in Table 1. Real-time RT-PCR was performed independently in triplicate for each of the different samples; the data are presented as the mean values of gene expression measured in treated samples versus controls.

\section{TUNEL assay}

Apoptotic cells were assayed using a DNA Fragmentation Imaging Kit (Roche) following the manufacturer's instructions. After the incubation period, the culture media were aspirated, and the cell layers were trypsinized. The trypsinized cells were reattached on $0.01 \%$ polylysine-coated slides,

Table I Primers used for qRT-PCR for the analysis of expression of proapoptotic and antiapoptotic genes

\begin{tabular}{llll}
\hline S no & Gene & Direction & Primers (5' -3') \\
\hline I & Bax & F & GAG AGG TCT TTT TCC GAG TGG \\
& & R & GGA GGA AGT CCA ATG TCC AG \\
2 & $P 53$ & F & AGG AAA TTT GCG TGT GGA GTA T \\
& & R & TCC GTC CCA GTA GAT TAC CAC T \\
3 & Bak & F & CTC AGA GTT CCA GAC CAT GTT G \\
& & R & CAT GCT GGT AGA CGT GTA GGG \\
4 & CAS3 & F & CAT ACT CCA CAG CAC CTG GTT A \\
& & R & ACT CAA ATT CTG TTG CCA CCT T \\
5 & CAS9 & F & ACT TTC CCA GGT TTT GTT TCC T \\
& & R & GAA ATT AAA GCA ACC AGG CAT C \\
6 & BCI2 & F & CTG AGT ACC TGA ACC GGC A \\
& & R & GAG AAA TCA AAC AGA GGC CG \\
7 & P2I & F & ATG TGG ACC TGT CAC TGT CTT G \\
& & R & CTT CCT CTT GGA GAA GAT CAG C \\
8 & Cyt-C & F & GCGTGTCCTTGGACTTAGAG \\
& & R & GGCGGCTGTGAAGAGATC \\
9 & GAPDH & F & AACGGATTTGGTCGTATTGGG \\
& & R & TCGCTCCTGGAAGATGGTGAT \\
\hline
\end{tabular}

Abbreviation: qRT-PCR, quantitative reverse transcriptase polymerase chain reaction. 
fixed with $4 \%$ methanol-free formaldehyde solution, and stained according to the manufacturer's instructions.

\section{Statistical analyses}

All assays were conducted in triplicate, and each experiment was repeated at least three times. The results are presented as means \pm standard deviation. All of the experimental data were compared using Student's $t$-test. A $P$-value of less than 0.05 was considered statistically significant.

\section{Results and discussion Synthesis and characterization of AgNPs using resveratrol}

Synthesis of AgNPs was conducted using resveratrol. Resveratrol, a polyphenolic compound present in grapes, plays a dual role by reducing metal ions and capping the small nanoparticles; these resveratrol-capped AgNPs show enhanced antibacterial activity. ${ }^{33}$ A previous study, conducted by our group, reported that resveratrol is a suitable reducing and stabilizing biological agent for the synthesis of grapheme. ${ }^{34}$ Additionally, resveratrol contains the Vitis vinifera fruit extract, used for the synthesis of AgNPs. ${ }^{35-37}$ Therefore, we selected resveratrol as the reducing and stabilizing agent for the synthesis of AgNPs. To produce smaller-sized AgNPs, $5 \mathrm{mM} \mathrm{AgNO}_{3}$ was added to $100 \mu \mathrm{M}$ of resveratrol and incubated for $6 \mathrm{~h}$ at $40^{\circ} \mathrm{C}$ and $\mathrm{pH}$ 8.0. Synthesis was confirmed by visual observation and ultraviolet (UV)-visible spectroscopy.

The characterization of synthesized AgNPs was conducted by analyzing UV-vis spectra. The spectra showed a maximum absorbance peak at $412 \mathrm{~nm}$ (Figure 1A), and peaks were observed at $412 \mathrm{~nm}$, corresponding to the surface plasmon resonance of AgNPs. ${ }^{20} \mathrm{We}$ examined the crystal nature of prepared AgNPs using X-ray diffraction (XRD). The sharp XRD peaks, at $2 \theta$ of 33.0, 45.0, and 64.3, were attributed to the crystallographic planes at (111), (200), and (220), respectively (Figure 1B). The assigned peaks at $2 \theta$ of $29.5^{\circ}$, $\left.{ }^{*}\right)$, may be related to the crystalline and amorphous organic phase. ${ }^{38,39}$ Fourier transform infrared spectroscopy was used to determine whether the potential biomolecules are involved in the reduction of $\mathrm{Ag}^{+}$ions and can serve as capping agents for AgNPs. ${ }^{34}$ Figure $1 \mathrm{C}$ shows the Fourier transform infrared spectra for AgNPs, which displays typical characteristics of AgNPs such as peaks at 3,285 and $1,639 \mathrm{~cm}^{-1}$; these peaks are characteristic of the $\mathrm{O}-\mathrm{H}$ and $\mathrm{C}=\mathrm{O}$ stretching modes for the $\mathrm{OH}$ and $\mathrm{C}=\mathrm{O}$ groups, which may be the functional groups in the culture supernatant. ${ }^{27}$ The presence of bonds owing to the stretching of $\mathrm{O}-\mathrm{H}$ (around 3,285 $\mathrm{cm}^{-1}$ ) and the
$\mathrm{C}=\mathrm{O}$ group (around 1,639 $\mathrm{cm}^{-1}$ ) can be attributed to the vibrations caused by the amide I.

Distribution by particle size was conducted to determine the toxicity of synthesized AgNPs. We conducted dynamic light scattering, which showed sizes between 3 and $20 \mathrm{~nm}$ (Figure 1D) with an average size of $6 \mathrm{~nm}$, and the polydispersity indexes of the prepared nanoparticles are 0.113 . The size and polydispersity indexes of silver nanoparticles and GEM were $20 \mathrm{~nm}$ and 0.123 respectively. Further, zeta potential of silver nanoparticles and silver nanoparticles containing GEM was calculated to be -21 and $-33 \mathrm{mV}$ respectively (Table 2). To verify the consistency of particle size, we used transmission electron microscopy (TEM), which can determine structural information such as the size and morphology of the nanoparticles. ${ }^{30}$ TEM micrographs indicated that particles were largely spherical in shape and well separated from each other (Figure 1E). More than 200 particles were measured using TEM; average particles size ranged between 3 and $20 \mathrm{~nm}$, with an average size of $6 \mathrm{~nm}$ (Figure 1F), which is consistent with the size obtained using dynamic light scattering.

\section{Effect of AgNPs and GEM on cell viability}

To determine the effect of GEM and AgNPs on cell viability, we first evaluated the effects of different concentrations of GEM and AgNPs on the viability of human ovarian cancer cells. As shown in Figure 2A, the cytotoxic effect of GEM was observed at $25 \mathrm{nM}$ after a 24-h incubation, whereas AgNPs showed increased cytotoxicity at $25 \mathrm{nM}$ after a 24-h incubation (Figure 2B). GEM and AgNPs inhibited the viability and growth of A2780 cells in a concentration-dependent manner. The median $50 \%$ inhibitory concentration $\left(\mathrm{IC}_{50}\right)$ of GEM and AgNPs after a 24-h exposure was 100 and 90 nM, respectively (Figure 2A and B). Although GEM and AgNPs showed a similar trend in inducing the loss of cell viability, the effect of AgNPs was slightly stronger than that of GEM. Cell viability was reduced significantly when the cells were treated with GEM; this agrees with previous reports on the activity of GEM in other cell types such as human pancreatic cancer cells and ARO thyroid cancer cells. Jiang et $\mathrm{al}^{40}$ reported that the $\mathrm{IC}_{50}$ of GEM after a 48 - $\mathrm{h}$ exposure is $16 \mu \mathrm{g} / \mathrm{mL}$, and Celano et $\mathrm{al}^{41}$ observed a significant effect at $100 \mu \mathrm{M}$ GEM after a 72-h treatment. Cell viability in SW1990 cells, treated with $20 \mu \mathrm{M}$ GEM, was reduced to $57 \%$ after $24 \mathrm{~h}^{42}$ Zhang et al ${ }^{43}$ demonstrated that GEM induced a dose- and time-dependent decrease in the proliferation of the lung cancer cell line SPC-A-1. Compared with that of the control cells, SPC-A-1 cells showed a $60 \%, 35 \%$, and $18 \%$ reduction in the levels 


\section{A}
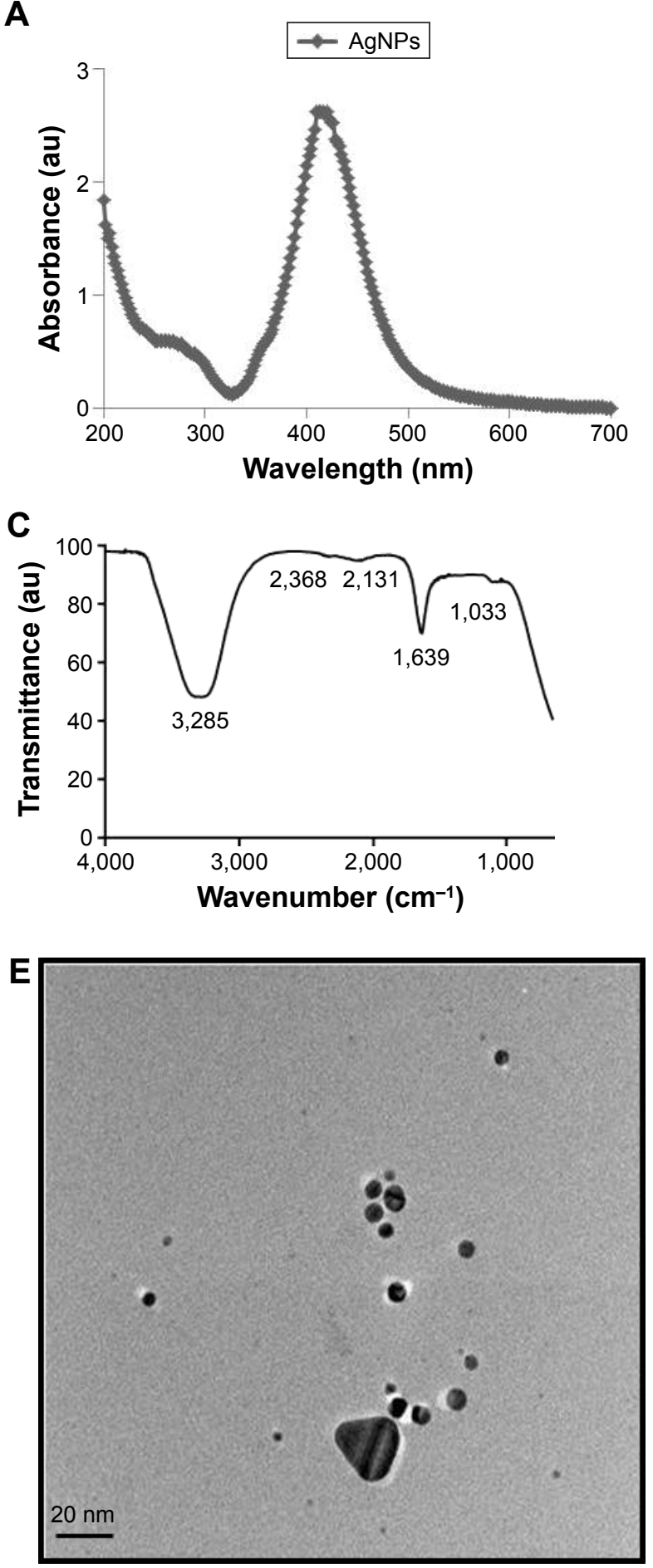

B

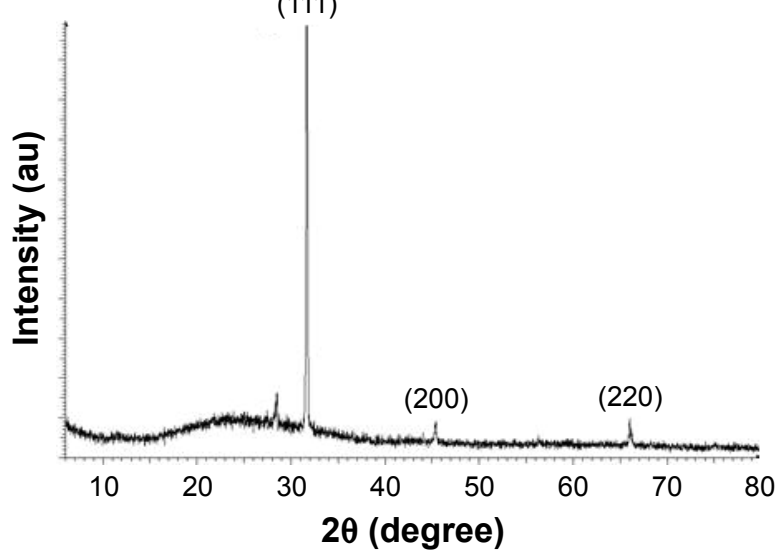

D Size distribution by intensity
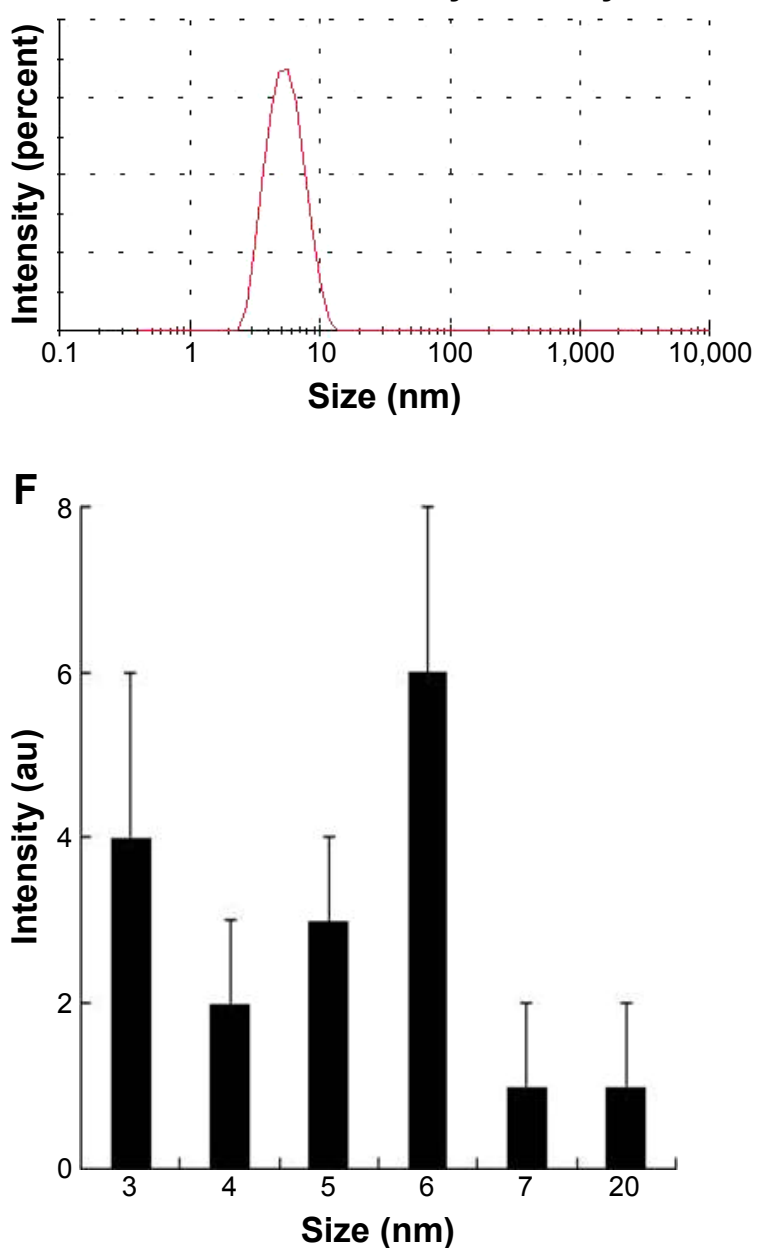

Figure I Synthesis and characterization of AgNPs using resveratrol.

Notes: (A) The absorption spectrum of AgNPs synthesized using resveratrol. (B) X-ray diffraction spectra of AgNPs. (C) Fourier transform infrared spectra of AgNPs. (D) Size distribution of AgNPs measured by dynamic light scattering. (E) TEM images of AgNPs. (F) Several fields were used to measure the particle size of AgNPs; micrograph shows size distributions based on TEM images of AgNPs ranging from 3 to $20 \mathrm{~nm}$.

Abbreviations: AgNPs, silver nanoparticles; TEM, transmission electron microscopy.

of proliferation after being treated with $40 \mathrm{mM}$ GEM for 24, 48, and 72 h, respectively. A2780 cells are more sensitive to GEM than to platinum agents. ${ }^{44,45}$ However, the extent to which GEM may influence cell viability depends on the dose of GEM and type of cells. The inhibitory concentration and dose-dependent effect of GEM in A2780 cells agreed with a previous report. The inhibitory effect of AgNPs was significantly stronger than that previously reported in human 
Table 2 Characteristics of AgNPs and AgNPs containing GEM (means, $\mathrm{n}=3$ )

\begin{tabular}{llll}
\hline $\begin{array}{l}\text { Type of } \\
\text { nanoparticles }\end{array}$ & $\begin{array}{l}\text { Mean particle } \\
\text { size }(\mathbf{n m})\end{array}$ & PDI & $\begin{array}{l}\text { Zeta potential } \\
(\mathbf{m V})\end{array}$ \\
\hline AgNPs & 10 & 0.113 & -21 \\
AgNPs + GEM & 20 & 0.123 & -33 \\
\hline
\end{tabular}

Abbreviations: AgNP, silver nanoparticle; GEM, gemcitabine; PDI, polydispersity index.

ovarian cancer cells; this may be because of the smaller size of AgNPs $(6 \mathrm{~nm})$ at less than $20 \mathrm{~nm} .{ }^{29}$ Several studies suggest that particle size determines the severity of toxicity in any exposed cell. ${ }^{46-48}$ Biologically synthesized AgNPs effectively inhibit the growth of A2780 cells, A549 lung cancer cells, MCF-7 breast cancer cells, and MDA-MB 231 cells; ;4,25,49 however, the toxicity of AgNPs may depend on the size of the particle. Sriram et al ${ }^{21}$ showed size-dependent toxicity in bovine retinal endothelial cells using two different sizes of biologically synthesized AgNPs. Recently, Kovacs et al ${ }^{31}$ reported that smaller nanoparticles possess higher cytotoxic properties compared with larger nanoparticles after a 24-h exposure. In that study, $5 \mathrm{~nm}$ AgNPs decreased cell viability at $15-20 \mu \mathrm{M}$, while a significant loss of metabolic activity was achieved only at $40 \mu \mathrm{M}$ with $35 \mathrm{~nm} \mathrm{AgNP}$ treatment. Collectively, our data suggest that smaller sized AgNPs, combined with GEM, can potentially inhibit the growth of cancer cells.

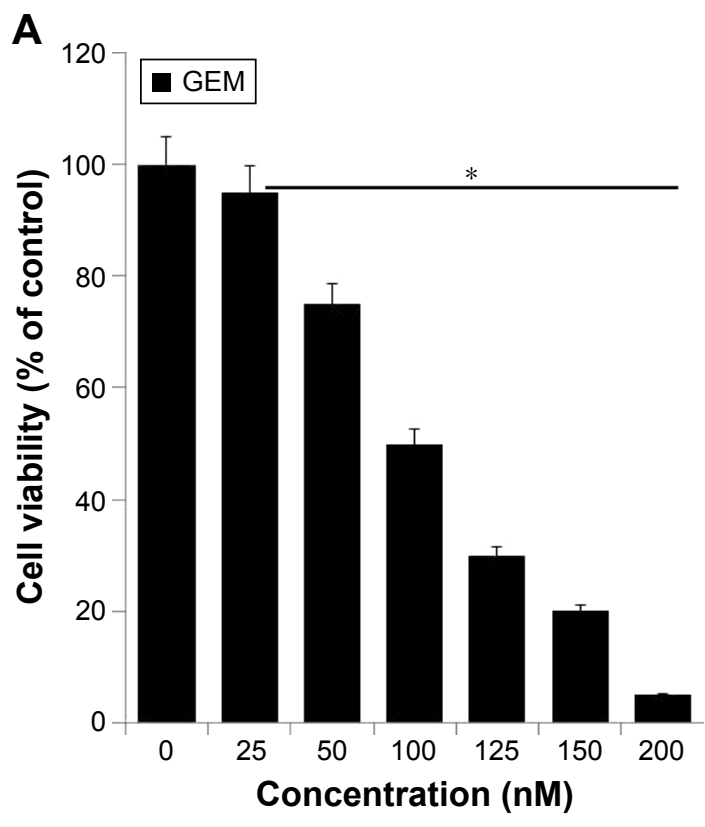

\section{Increased concentration of AgNPs combined with GEM decreases cell viability}

To examine the combined effect of GEM and AgNPs, we tested the $\mathrm{IC}_{25}$ concentration of GEM and AgNPs, because a lower concentration may prevent drug resistance, undesired side effects, and toxicity. GEM (50 nM) and AgNPs $(50 \mathrm{nM})$ were used to assess the combined cytotoxic effects of combined treatment. Cell viability in the A2780 cell line was determined using the WST-8 assay. As shown in Figure 3A, combined treatment with GEM and AgNPs enhanced apoptosis by $75 \%$ and decreased cell viability more efficiently than GEM (27\%) or AgNPs (23\%) alone. We then examined the effects of treating A2780 cells with different concentrations of AgNPs (50, 100, and $150 \mathrm{nM})$ added to a fixed concentration of GEM $(50 \mathrm{nM})$. The results show that increasing concentrations of AgNPs reduce cell viability more than do lower concentrations; however, the toxicity was substantially increased. This indicates that a lower concentration of AgNPs was sufficient to produce a strong synergistic effect with GEM to induce cell death in ovarian cancer cells (Figure 3B). Our results are consistent with an earlier study by Zhang et $\mathrm{al}^{50}$ reporting that combined treatment with Sal and GEM inhibited cell growth in pancreatic cancer cells more than did single treatment with either agent. ${ }^{47}$ The combination of Noxa and GEM significantly

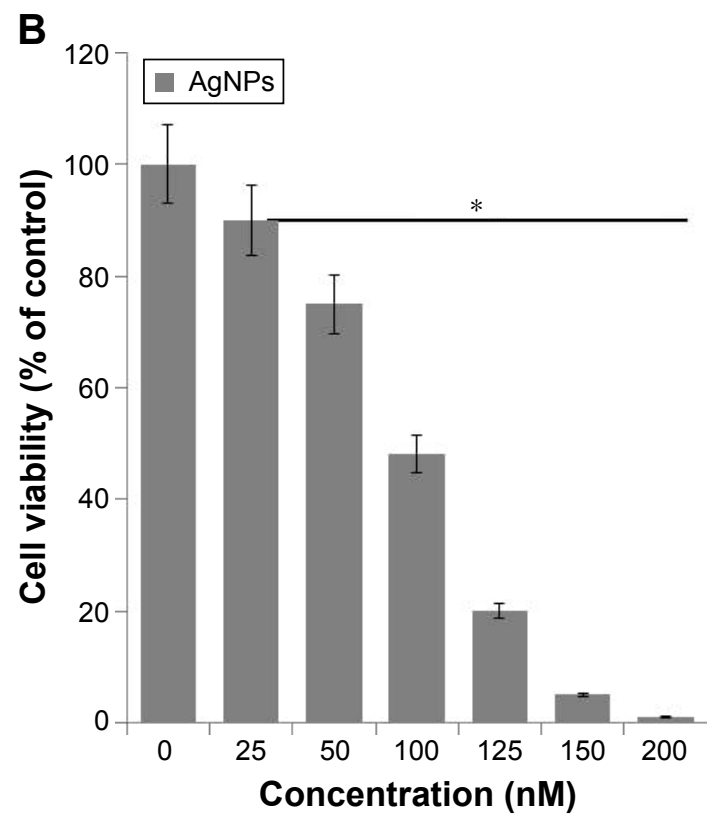

Figure 2 Dose-dependent effect of GEM and AgNPs on cell viability in human ovarian cancer cells.

Notes: (A) A2780 human ovarian cancer cells were incubated with various concentrations of GEM (25-200 nM) for 24 h, and cell viability was measured using WST-8. (B) A2780 were incubated with various concentrations of AgNPs (25-200 nM) for $24 \mathrm{~h}$, and cell viability was measured using WST-8. The results are expressed as the mean \pm standard deviation of three separate experiments. Differences between the treated and control groups were measured using Student's $t$-test. Statistically significant differences between the treated and control group are indicated by $(* P<0.05)$.

Abbreviations: AgNP, silver nanoparticle; GEM, gemcitabine. 

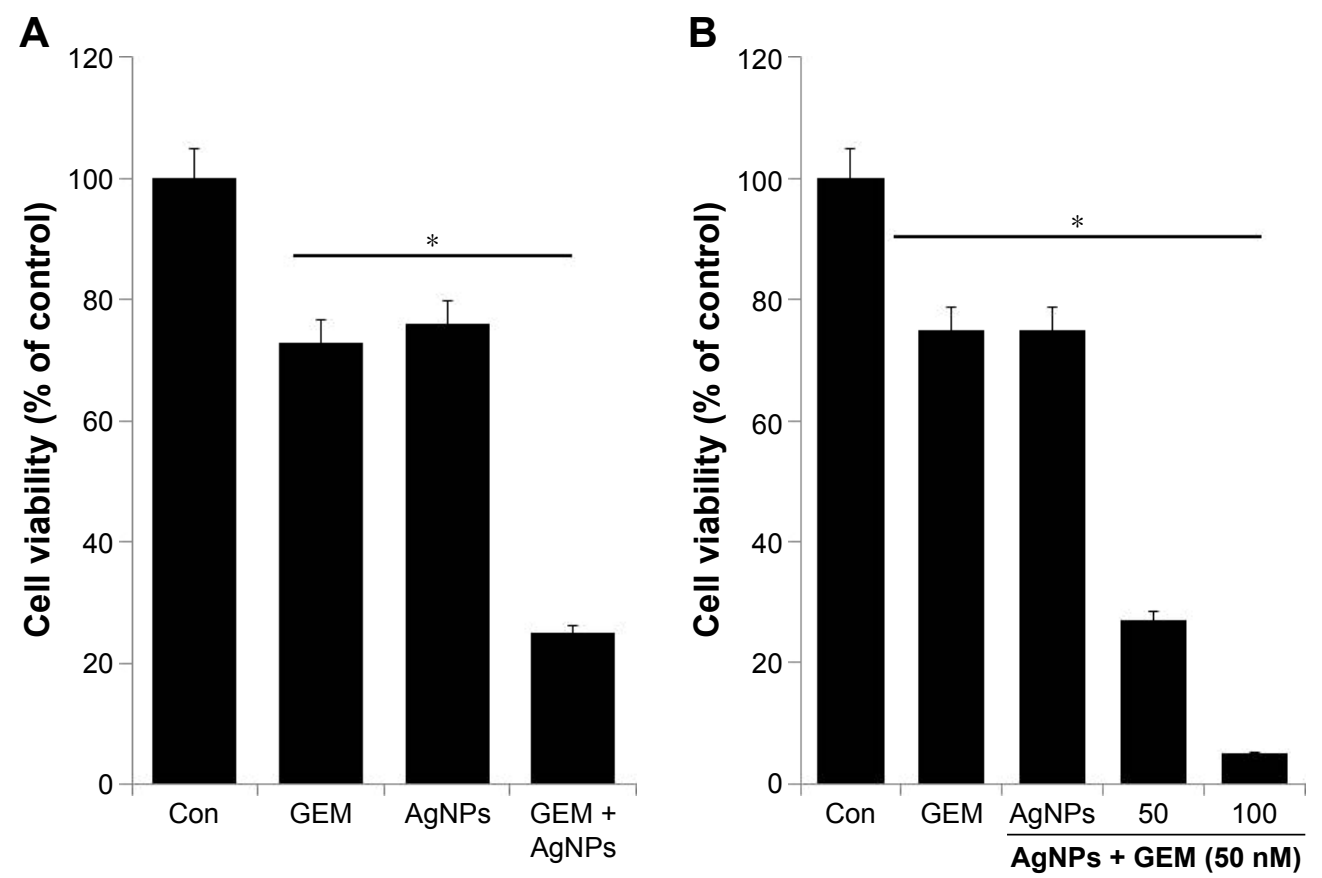

Figure 3 The effect of combined treatment with GEM and AgNPs on cell viability in human ovarian cancer cells.

Notes: (A) A2780 were incubated with GEM ( $50 \mathrm{nM}$ ) and AgNPs (50 nM). (B) A2780 cells were incubated with a combination of different concentrations of AgNPs (50 and $100 \mathrm{nM})$ and a fixed concentration of GEM $(50 \mathrm{nM})$ for $24 \mathrm{~h}$. The results are expressed as the mean \pm standard deviation of three separate experiments. Differences between the treated and control groups were measured using Student's $t$-test. Statistically significant differences between the treated and control group are indicated by $(* P<0.05$ ). Abbreviations: AgNP, silver nanoparticle; Con, control; GEM, gemcitabine.

inhibited the proliferation of A2780 and COC1 cells, as well as the growth of tumor xenografts, by inhibiting growth and inducing apoptosis. ${ }^{51}$

\section{Effect of GEM and AgNPs on morphology of $A 2780$ cells}

Next, we determined the morphological changes in cells treated with $50 \mathrm{nM}$ GEM, $50 \mathrm{nM} \mathrm{AgNPs}$, or a combination of $50 \mathrm{nM}$ GEM and $50 \mathrm{nM}$ AgNPs. The morphology of control and treated cells was observed using an Olympus microscope at a magnification of $200 \times$ at $24 \mathrm{~h}$ posttreatment. The controls cells were intact and had proliferated and reached confluence by $24 \mathrm{~h}$ of cultivation; the cells treated with $50 \mathrm{nM}$ GEM, $50 \mathrm{nM}$ AgNPs, or a combination of $50 \mathrm{nM}$ GEM and $50 \mathrm{nM}$ AgNPs gradually lost their adherence to the surface and displayed intensive blebbing, which is typical for apoptotic cell death. ${ }^{51}$ The earliest changes in morphology were detected after treatment with AgNPs, followed by that with GEM (Figure 4). Previous reports suggest that AgNPs can potentially influence the morphology of several types of cells including bovine retinal endothelial cells ${ }^{9,47}$ and ovarian cancer cells. ${ }^{24}$ GEM induced the appearance of numerous rounded cells and decreased cell density. After combined treatment with GEM and AgNPs, cellular fragmentation occurred extensively and adherent properties of the cells were compromised. Similarly, the combination of emodin and GEM strongly induces the appearance of rounded SW1990/GZ cells and decreases cell density. ${ }^{53}$

\section{Effect of GEM and AgNPs on cell proliferation}

The proliferation assay is crucial for determining drug efficacy. The antiproliferative effect of GEM and AgNPs at the selected concentrations was determined by the incorporation of BrdU. To investigate whether AgNPs and GEM can kill cancer cells by attacking different or identical cellular targets, we treated A2780 cells with $50 \mathrm{nM} \mathrm{GEM,} 50 \mathrm{nM}$ AgNPs, or a combination of $50 \mathrm{nM}$ GEM and $50 \mathrm{nM}$ AgNPs. The proliferating efficiency of A2780 cells decreased after treatment with GEM and AgNPs (Figure 5A). These data are consistent with the results of the cell viability studies using WST-8, suggesting that the loss of viable cells caused by GEM, AgNPs, or the combination of the two is the result of the induction of apoptosis. The combination of Noxa and GEM significantly inhibited the proliferation of A2780 and COC1 cells. ${ }^{51}$ Yong-Xian et al ${ }^{54}$ demonstrated that GEM significantly inhibited cell proliferation in a dose-dependent manner, which is the main reason for apoptosis in human pancreatic 

cancer PANC-1. We further examined the combined effect of GEM and AgNPs on cytotoxicity by counting the numbers of viable cells using the trypan blue exclusion assay in cells treated with $50 \mathrm{nM}$ GEM, $50 \mathrm{nM}$ AgNPs, or a combination of $50 \mathrm{nM}$ GEM and $50 \mathrm{nM}$ AgNPs for $24 \mathrm{~h}$. The gradual decrease in the number of viable A2780 cells after combined treatment with GEM and AgNPs was greater than that after treatment with GEM or AgNPs alone (Figure 5B). The results of the cell proliferation assay were consistent with those of the trypan blue exclusion assay.

\section{Combined treatment with GEM and AgNPs enhances cytotoxicity}

The leakage of lactate dehydrogenase is a marker for the detection of apoptosis and cytotoxicity. ${ }^{55}$ Infection with influenza virus type A induces leakage of LDH from cultured chorionic cells; this is accompanied by degradation typical in apoptotic cells, such as fragmentation of oligonucleosomal DNA, and condensation and fragmentation of the nucleus. ${ }^{56,57}$ Assessing the release of intracellular LDH, which occurs because of the breakdown and alteration in the permeability of the plasma membrane, is a commonly used marker for estimating cytotoxicity. ${ }^{58}$ Therefore, we treated A2780 cells with $50 \mathrm{nM}$ GEM, $50 \mathrm{nM}$ AgNPs, or a combination of $50 \mathrm{nM}$ GEM and $50 \mathrm{nM}$ AgNPs for $24 \mathrm{~h}$ and then measured the leakage of $\mathrm{LDH}$. Our results indicate that treatment with
GEM and AgNPs induced a significant amount of LDH leakage in cultured A2780 cells (Figure 6A). Treatment with GEM induced a moderate amount of LDH leakage, whereas AgNP-treated cells showed a considerable amount of LDH leakage compared with that in untreated cells. Zhang and Gurunathan $^{27,59}$ showed increased leakage of LDH in A2780 cells treated with AgNPs compared with that in cells treated with salinomycin. Similarly, the leakage of LDH in human cervical cancer cells, treated with nanoparticles of palladium, was increased compared with that in cells treated with trichostatin A. Collectively, these results suggest that nanoparticles may be more effective for inducing LDH leakage than other chemical agents.

Then, we used the dead-cell protease activity assay to demonstrate the combined effect of GEM and AgNPs on the viability of A2780 cells. Cell viability was calculated according to the manufacturer instructions and a previously reported method. ${ }^{33}$ In A2780 cells treated with GEM (50 nM) or AgNPs (50 nM), viability decreased by $30 \%$ and $35 \%$, respectively. Combined treatment with GEM and AgNPs decreased viability by $70 \%$ (Figure 6B). These results indicate that the viability of A2780 cells was significantly reduced by the combined treatment, which is a similar pattern to that observed with LDH leakage. These results suggest that combined treatment with GEM and AgNPs was significantly more cytotoxic than single treatment with either agent.
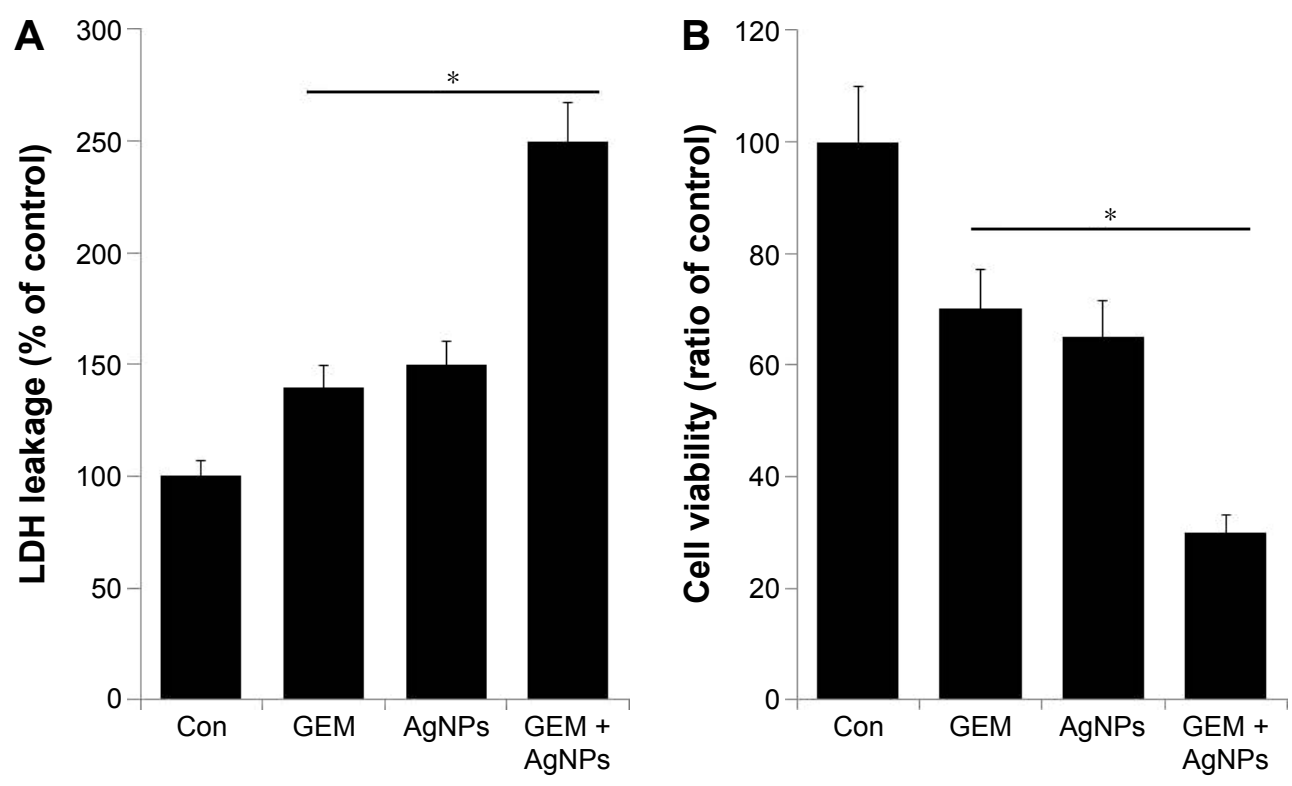

Figure 6 The cytotoxicity of GEM, AgNPs, or combined treatment with GEM and AgNPs in human ovarian cancer cells.

Notes: (A) A2780 cells were treated with GEM (50 nM), AgNPs (50 nM), or a combination of GEM (50 nM) and AgNPs ( 50 nM) for 24 h. The activity of LDH was measured at $490 \mathrm{~nm}$ using the LDH cytotoxicity kit. (B) The level of dead-cell protease was determined by CytoTox-Glo cytotoxicity assay. The results are expressed as the mean \pm standard deviation of three independent experiments. Differences between the treated and control groups were measured using Student's $t$-test. Statistically significant differences between the treated and control group are indicated by $(* P<0.05)$.

Abbreviations: AgNP, silver nanopaeticle; Con, control; GEM, gemcitabine; LDH, lactate dehydrogenase. 


\section{Combined treatment with GEM and AgNPs targets ROS generation and mitochondrial dysfunction}

Next, we examined the effect of GEM and AgNPs on the generation of ROS. Generation of ROS is a cytotoxic mechanism. ROS are the byproducts of normal cellular oxidative processes involved in the initiation of apoptotic signaling ${ }^{57}$ and various cellular functions including proliferation, growth, and invasion. ${ }^{55}$ To assess the effect of GEM and AgNPs on the generation of ROS, A2780 cells were treated with $50 \mathrm{nM}$ GEM, $50 \mathrm{nM}$ AgNPs, or a combination of $50 \mathrm{nM}$ GEM and $50 \mathrm{nM}$ AgNPs for $24 \mathrm{~h}$; then, the levels of ROS were measured using DCFH-DA. Although single treatment with GEM or AgNPs induced generation of ROS, AgNPs induced significantly higher levels compared with those induced by GEM (Figure 7A); this is consistent with previous reports demonstrating that AgNPs induce pronounced cytotoxicity in various types of cancer cells including human breast, ovarian, lung, and germ cells. ${ }^{24,25,29,60,61}$ Interestingly, N-acetyl cysteine was able to significantly decrease the levels of ROS that had been induced by GEM, AgNPs, or a combination of GEM and AgNPs, indicating that production of ROS plays a critical role in GEM- and AgNP-induced cytotoxicity. Kovacs et $\mathrm{al}^{31}$ demonstrated that osteosarcoma cells treated with $20 \mu \mathrm{M}$ AgNPs $(5 \mathrm{~nm})$ and $85 \mu \mathrm{M}$ AgNPs $(35 \mathrm{~nm})$ produced considerable levels of ROS; this study additionally confirmed that mitochondrial dysfunction is coupled to oxidative stress. The combination of GEM and cannabinoids triggers autophagy in pancreatic cancer cells via a ROS-mediated mechanism. ${ }^{62}$ GEM can induce ROS generation in pancreatic cancer stem cells, leading to increased chemosensitivity. ${ }^{63}$ Together, our results indicate that combined treatment with GEM and AgNPs induced significant cytotoxicity in A2780 cells via generation of ROS.

The generation of ROS increases the permeability of the mitochondrial membrane, which leads to the induction of apoptosis. ${ }^{64}$ Therefore, we investigated the mechanistic effect of combined treatment with GEM and AgNPs on A2780 cells. The cells were treated with 50 nM GEM, 50 nM AgNPs, or a combination of $50 \mathrm{nM}$ GEM and $50 \mathrm{nM}$ AgNPs for $24 \mathrm{~h}$, after which MMP was examined using the JC-1 probe. The fluorescence values indicated that GEM and AgNPs together induced a decrease in MMP; however, treatment with GEM alone caused only a moderate decrease compared with a more pronounced decrease observed in AgNP-treated cells. Combined treatment with GEM and AgNPs induced a significant
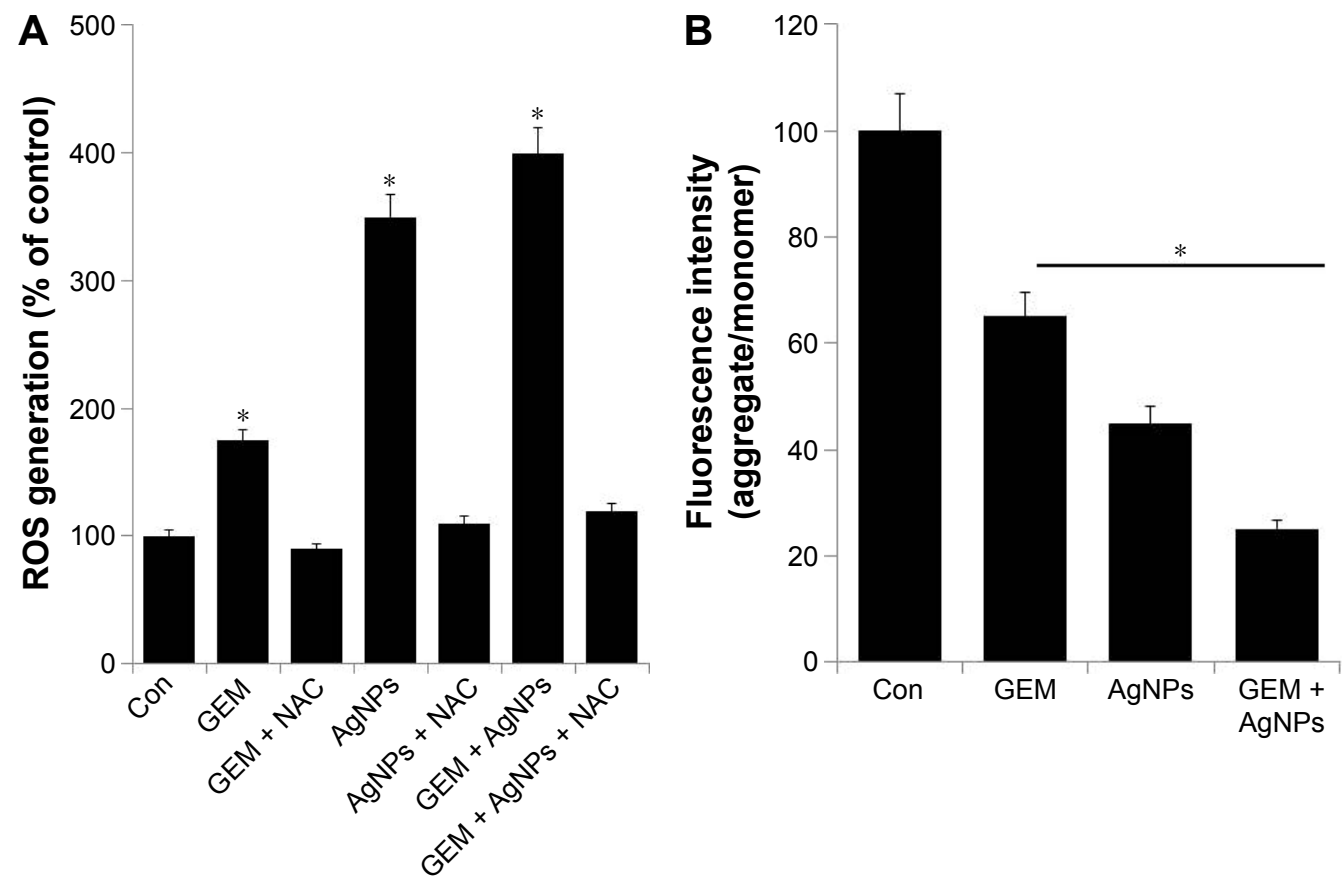

Figure 7 The effect of GEM, AgNPs, or a combination of GEM and AgNPs on oxidative stress in human ovarian cancer cells.

Notes: (A) The levels of ROS were assessed by measuring the relative fluorescence of $2^{\prime}, 7^{\prime}$-dichlorofluorescein using a spectrofluorometer. (B) Cells were treated with GEM (50 nM), AgNPs (50 nM), or the combination of GEM (50 nM) and AgNPs (50 nM) for $24 \mathrm{~h}$; MMP (measured as a ratio of JC-I aggregate to monomer) was determined after the treatments. The results are expressed as the mean \pm standard deviation of three independent experiments. Differences between the treated and control groups were measured using Student's $t$-test. Statistically significant differences between the treated and control group are indicated by $(* P<0.05)$.

Abbreviations: AgNP, silver nanoparticle; Con, control; GEM, gemcitabine; MMP, mitochondrial membrane potential; NAC, N-acetyl cysteine; ROS, reactive oxygen species. 
decrease in MMP compared with that in untreated control cells (Figure 7B). Seol et al ${ }^{65}$ reported that pretreatment with gemcitabine, followed by treatment with TRAIL, reduces mitochondrial transmembrane potential in A549 cells. Previous studies suggest that AgNPs can induce the loss of mitochondrial membrane potential in human lung cancer cells $^{35}$ as well as in U2Os and Saos-2 cells. ${ }^{35,66}$

Free radical generation is related to the loss of mitochondrial inner membrane potential and is considered one of the cytotoxic effects of GEM; ${ }^{67}$ however, a similar phenomenon, observed in human lung cancer cells, is also induced by AgNPs. ${ }^{35,50}$ Collectively, this study suggests that mitochondrial dysfunction is coupled with oxidative stress in GEM- and AgNP-treated cells. This study also indicates that the elevation of ROS in A2780 cancer cells is caused by an imbalance between pro- and antioxidant enzymes, ${ }^{27,55}$ which occurs when the cells are exposed to anticancer agents; this exhausts the cellular antioxidant capacity and leads to apoptosis.

\section{Effect of GEM and AgNPs on pro- and antiapoptotic gene expression in A2780 cells}

Programmed cell death plays an important role in tumors because pro- and antiapoptotic factors are simultaneously activated in tumor development and progression. Indeed, apoptosis is one of the major consequences of chemotherapy. To assess apoptotic activity caused by GEM and AgNPs in A2780 cells, A2780 cells were treated with 50 nM GEM, $50 \mathrm{nM}$ AgNPs, or a combination of $50 \mathrm{nM}$ GEM and $50 \mathrm{nM}$ AgNPs for $24 \mathrm{~h}$, after which gene expression was measured by RT-PCR. As shown in Figure 8, treatment with GEM alone, and combined treatment with GEM and AgNPs, downregulated the expression of Bcl-2, but upregulated the expression of p53, p21, Bax, Bak, and caspase-9 and -3. p53 can inhibit cell growth via activation of cell cycle arrest and apoptosis. Our results suggest that GEM and AgNPs can upregulate the expression of p53 and p21. Hill et al ${ }^{68}$ reports that GEM strongly induces p53-dependent apoptosis, which correlates with the accumulation of proapoptotic proteins, such as PUMA and Bax, in human colon cancer cells. In A2780 cells, the upregulation of p53 is accompanied by increased expression of $\mathrm{p} 21$, indicating that AgNPs sensitize the cells to apoptosis. A similar phenomenon was observed in A2780 cells treated with a combination of salinomycin and AgNPs. ${ }^{69}$ p53 can directly interact with Bax to induce permeabilization of mitochondria. Bax induces apoptosis in cancer cells via p53-dependent and p53-independent pathways; cooperation between $\mathrm{p} 53$ and Bax can induce apoptosis. ${ }^{70}$ Members of the Bcl-2 protein family, such as
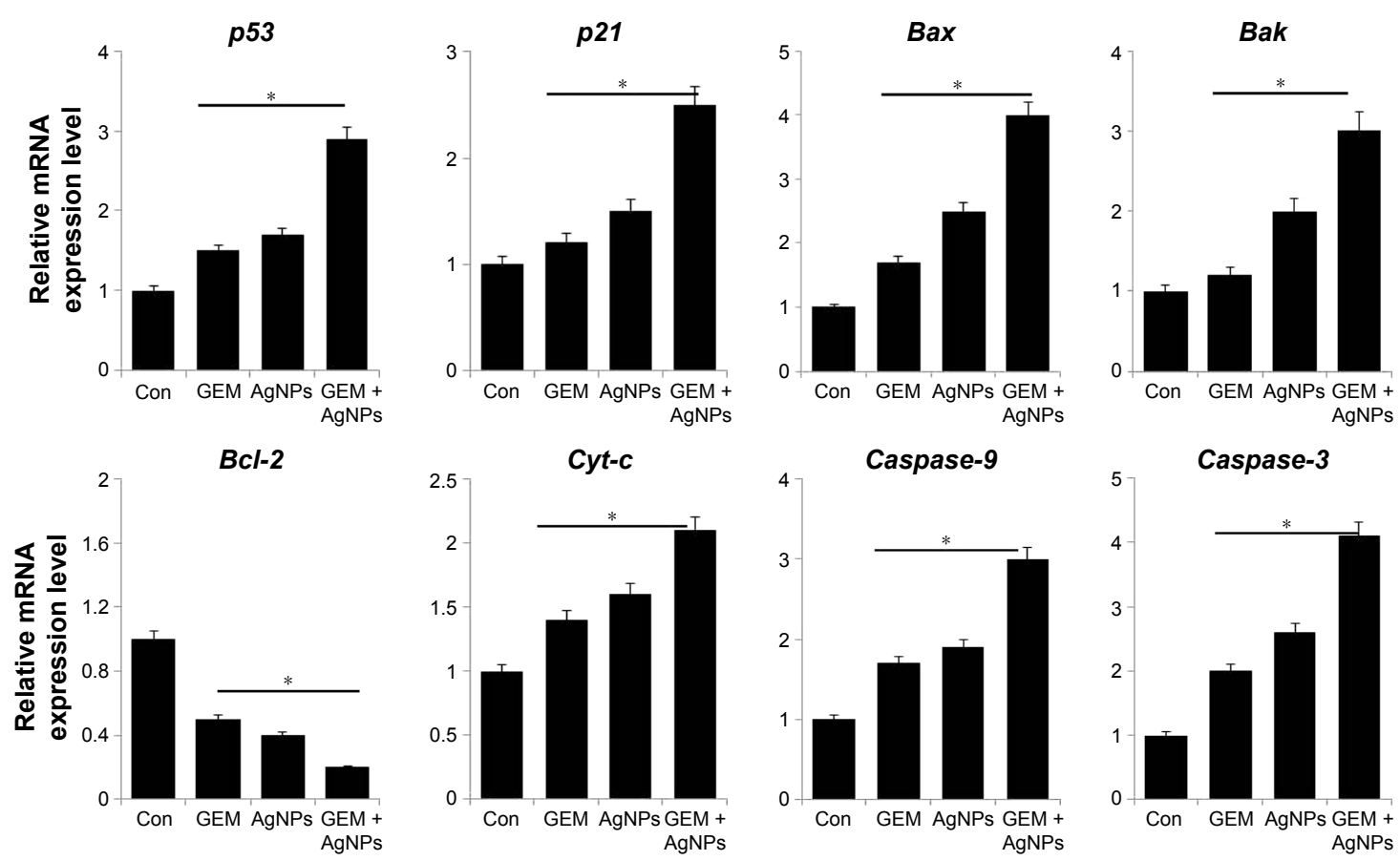

Figure 8 The effect of combined treatment with GEM and AgNPs on the expression of proapoptotic and antiapoptotic genes.

Notes: Relative mRNA expression was analyzed using qRT-PCR in human ovarian cancer cells after treatment with GEM (50 nM), AgNPs (50 nM), or a combination of GEM $(50 \mathrm{nM})$ and $\mathrm{AgNPs}(50 \mathrm{nM})$, for $24 \mathrm{~h}$. The results are expressed as the mean \pm standard deviation of three separate experiments. Differences between the treated and control groups were measured using Student's $t$-test. Statistically significant differences between the treated and control group are indicated by $(* P<0.05)$.

Abbreviations: AgNP, silver nanoparticle; Con, control; GEM, gemcitabine; qRT-PCR, quantitative reverse transcriptase polymerase chain reaction. 

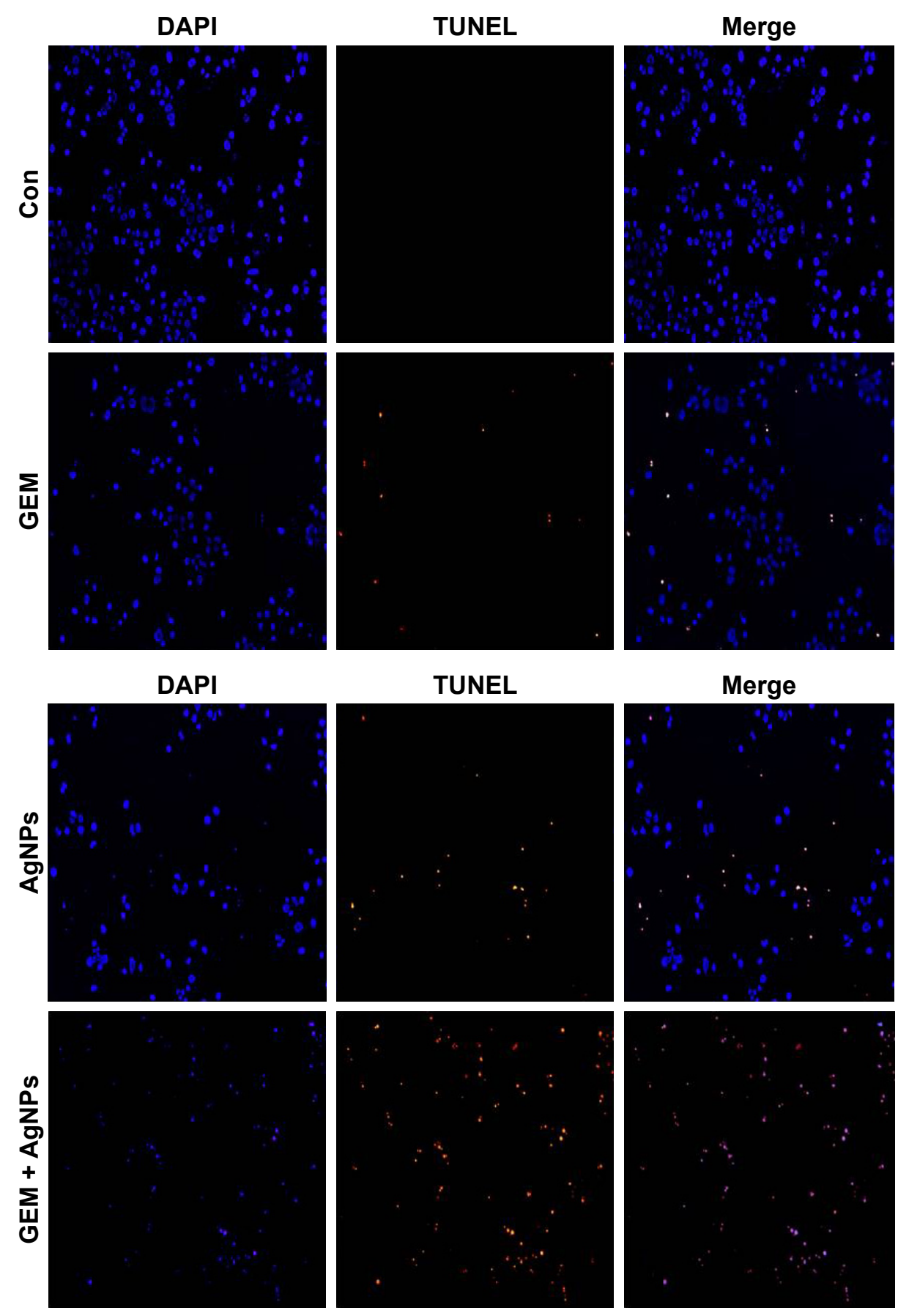

Figure 9 The effect of treatment with GEM, AgNPs, or a combination of GEM and AgNPs, on apoptosis in human ovarian cancer cells.

Notes: The cells were treated with GEM (50 nM), AgNPs (50 nM), or a combination of GEM (50 nM) and AgNPs (50 nM), for 24 h. Apoptosis in human ovarian cancer cells after a 24-h treatment was assessed using the TUNEL assay; the nuclei were counterstained with DAPI. Representative images show apoptotic (fragmented) DNA (red staining) and the corresponding cell nuclei (blue staining).

Abbreviations: AgNP, silver nanoparticle; Con, control; GEM, gemcitabine.

the antiapoptotic protein Bcl-2 and proapoptotic proteins Bax and Bak, play important roles in mitochondria-mediated apoptosis. ${ }^{71,72}$ Downregulation of Bcl-2 and upregulation of Bax can induce the release of cytochrome $\mathrm{C}$ from the mitochondria into the cytosol, triggering the activity of caspase-3 and -9 and eventually causing apoptosis. ${ }^{73}$ AgNPs can induce apoptosis via extrinsic and intrinsic pathways in a process that is mediated by several caspases. ${ }^{61,74}$ The human A549 lung cancer cells, treated with GEM, show increased levels of caspase- $3 .^{75}$ This suggests that the A2780 cells treated with AgNPs, or a combination of AgNPs and GEM, may upregulate their levels of caspases 9 and 3. Collectively, our results show that the combination of GEM and AgNPs induces caspase-mediated apoptosis in A2780 cells. 


\section{GEM and AgNPs induce apoptosis}

Apoptosis is a fundamental biological process involved in development, differentiation, and homeostasis. Various agents, such as chemotherapeutic drugs, inhibitors of growth factors, or nanoparticles, can be used to induce morphological changes including cell shrinkage, fragmentation of the nucleus, and activation of caspases, resulting in apoptosis. ${ }^{76,77}$ The cellular assays used in our study indicate that treatment with GEM or AgNPs, or a combined treatment with GEM and AgNPs, induced the loss of cellular viability. Therefore, we assayed fragmentation of DNA as the final hallmark of apoptosis. A2780 cells were treated with $50 \mathrm{nM}$ GEM, $50 \mathrm{nM}$ AgNPs, or a combination of $50 \mathrm{nM}$ GEM and $50 \mathrm{nM}$ AgNPs for $24 \mathrm{~h}$, after which the TUNEL assay was used to observe TUNEL-positive cells. The results indicate that single treatment with GEM or AgNPs induced fragmentation of DNA; however, the effect was more pronounced in AgNPs-treated cells. Combined treatment with GEM and AgNPs produced a significantly higher number of TUNELpositive cells (Figure 9). Previous studies suggest that GEM can induce apoptosis via DNA fragmentation in a variety of cancer cells including human lymphoblastoid cells, ${ }^{77}$ HT-29 colon cancer cells, ${ }^{78}$ and human non-small-cell lung cancer cells. ${ }^{79}$ Similarly, AgNPs can induce apoptosis in human MDA-MB231 breast cancer cells ${ }^{24,29}$ and ovarian cancer cells. ${ }^{27}$ DNA fragmentation is a series of cleavage events involving the excision of large fragments of DNA. A study using human lymphoblastoid cells demonstrated that GEM can incorporate into the DNA and inhibit DNA synthesis, ${ }^{77}$ inducing DNA damage response and degradation of PARP1 via autophagy. ${ }^{80}$ In summary, our results indicate that the combination of GEM and AgNPs synergistically induces apoptosis in A2780 cells via DNA fragmentation.

\section{Conclusion}

GEM and AgNPs potentially induce cytotoxicity in various types of cancer cells. However, there are no conclusive data on the combined effects of GEM and AgNPs in human ovarian cancer cells. Therefore, this study aimed to develop new modalities for cancer treatment using in vitro culture as a model system. Currently, there is an urgent need for new treatment options and improved understanding of how GEM and AgNPs synergistically induce anticancer effects. In this study, we used the novel biomolecule resveratrol to synthesize AgNPs with an average size of $6 \mathrm{~nm}$. We demonstrated that GEM and AgNPs exert anticancer effects by decreasing cell viability and proliferation and by inducing increased leakage of LDH and generation of ROS. The combined treatment with GEM and AgNPs led to an upregulation in the expression of proapoptotic genes, including P53, P21, Bax, $B a k, c y t-c$, caspase-9, and caspase 3, and downregulation in the expression of Bcl-2. The combination of GEM and AgNPs induced significant DNA fragmentation in A2780 cells. This study will be useful for the development of combination-based therapeutic strategies for ovarian cancer. However, further studies are needed to elucidate the detailed mechanism of signaling pathways involved in GEM- and AgNPs-induced apoptosis.

\section{Acknowledgments}

This paper was supported by the KU-Research Professor Program of Konkuk University. This study was also supported by a Project Funded by the Priority Academic Program Development of Jiangsu Higher Education Institutions (PAPD) and China Postdoctoral Science Foundation (2015M571827/1402001C).

\section{Disclosure}

The authors report no conflicts of interest in this work.

\section{References}

1. American Cancer Society. Cancer Facts \& Figures 2016. Atlanta: American Cancer Society; 2016.

2. Siegel RL, Miller KD, Jema A. Cancer Statistics, 2016. CA Cancer J Clin. 2016;66:7-30.

3. IARC CancerBase No. 11. [database on the Internet]. International Agency for Research on Cancer. GLOBOCAN 2012 v1.0, Cancer Incidence and Mortality Worldwide. Available from: globocan.iarc.fr. Accessed December 6, 2016.

4. Torre LA, Bray F, Siegel RL, Ferlay J, ME Lortet-Tieulent J, Jemal A. Global Cancer Statistics, 2012. Ca Cancer J Clin. 2015;65(2): 87-108.

5. Jemal A, Thomas A, Murray T, Murray T, Xu J, Thun MJ. Cancer statistics. CA Cancer J Clin. 2002;52:23-47.

6. Kawaguchi H, Terai Y, Tanabe A, et al. Gemcitabine as a molecular targeting agent that blocks the Akt cascade in platinum-resistant ovarian cancer. J Ovarian Res. 2014;7:38.

7. McGuire WP, Hoskins WJ, Brady MF, et al. Cyclophosphamide and cisplatin compared with paclitaxel and cisplatin in patients with stage III and stage IV ovarian cancer. $N$ Engl J Med. 1996; 334(1):1-6.

8. Gadducci A, Iacconi, Fanucchi, Cosio, Miccoli, Genazzani. Survival after intestinal obstruction in patients with fatal ovarian cancer: Analysis of prognostic variables. Int J Gynecol Cancer. 1998;8:177-182.

9. Chabner BA, Roberts TG. Timeline: Chemotherapy and the war on cancer. Nat Rev Cancer. 2005;5(1):65-72.

10. DeVita VT, Chu E. A history of cancer chemotherapy. Cancer Res. 2008;68(21):8643-8653.

11. Sun X, Zhang J, Gupta R, Macgibbon AK, Kuhn-Sherlock B, Krissansen GW. Dairy milk fat augments paclitaxel therapy to suppress tumour metastasis in mice, and protects against the side-effects of chemotherapy. Clin Exp Metastasis. 2011;28(7):675-688.

12. Lane D, Côté M, Grondin R, Couture MC, Piché A. Acquired resistance to TRAIL-induced apoptosis in human ovarian cancer cells is conferred by increased turnover of mature caspase-3. Mol Cancer Ther. 2006; 5(3):509-521. 
13. Sengupta S, Eavarone D, Capila I, et al. Temporal targeting of tumour cells and neovasculature with a nanoscale delivery system. Nature. 2005;436(7050):568-572.

14. Toschi L, Finocchiaro G, Bartolini S, Gioia V, Cappuzzo F. Role of gemcitabine in cancer therapy. Future Oncol. 2005;1(1):7-17.

15. Arpicco S, Lerda C, Dalla Pozza E, et al. Hyaluronic acid-coated liposomes for active targeting of gemcitabine. Eur J Pharm Biopharm. 2013;85(3PtA):373-380.

16. Paolino D, Cosco D, Gaspari M, et al. Targeting the thyroid gland with thyroid-stimulating hormone (TSH)-nanoliposomes. Biomaterials. 2014;35(25):7101-7109.

17. Cosco D, Paolino D, De Angelis F, et al. Aqueous-core PEG-coated PLA nanocapsules for an efficient entrapment of water soluble anticancer drugs and a smart therapeutic response. Eur J Pharm Biopharm. 2015;89(10):30-39.

18. Mignani S, Bryszewska M, Klajnert-Maculewicz B, Zablocka M, Majoral JP. Advances in combination therapies based on nanoparticles for efficacious cancer treatment: an analytical report. Biomacromolecules. 2015;16(1):1-27.

19. Hu CM, Zhang L. Therapeutic nanoparticles to combat cancer drug resistance. Curr Drug Metab. 2009;10(8):836-841.

20. Cho K, Wang X, Nie S, Chen ZG, Shin DM. Therapeutic nanoparticles for drug delivery in cancer. Clin Cancer Res. 2008;14(5): 1310-1316.

21. Sriram MI, Kanth SB, Kalishwaralal K, Gurunathan S. Antitumor activity of silver nanoparticles in Dalton's lymphoma ascites tumor model. Int J Nanomedicine. 2010;5:753-762.

22. Kalishwaralal K, Banumathi E, Ram Kumar Pandian S. Silver nanoparticles inhibit VEGF induced cell proliferation and migration in bovine retinal endothelial cells. Colloids Surf B Biointerfaces. 2009;73(1):51-57.

23. Gurunathan S, Kalishwaralal K, Vaidyanathan R, et al. Biosynthesis, purification and characterization of silver nanoparticles using Escherichia coli. Colloids Surf B Biointerfaces. 2009;74(1):328-335.

24. Gurunathan S, Park JH, Han JW, Kim JH. Comparative assessment of the apoptotic potential of silver nanoparticles synthesized by Bacillus tequilensis and Calocybe indica in MDA-MB-231 human breast cancer cells: targeting p53 for anticancer therapy. Int J Nanomedicine. 2015; 10:4203-4222.

25. Gurunathan S, Han JW, Eppakayala V, Jeyaraj M, Kim JH. Cytotoxicity of biologically synthesized silver nanoparticles in MDAMB-231 human breast cancer cells. Biomed Res Int. 2013;2013: 535796.

26. Zuberek M, Wojciechowska D, Krzyzanowski D, MeczynskaWielgosz S, Kruszewski M, Grzelak A. Glucose availability determines silver nanoparticles toxicity in HepG2. J Nanobiotechnology. 2015; $13: 72$.

27. Zhang XF, Gurunathan S. Combination of salinomycin and silver nanoparticles enhances apoptosis and autophagy in human ovarian cancer cells: an effective anticancer therapy. Int J Nanomedicine. 2016; 11:3655-3675

28. Lin J, Huang $\mathrm{Z}, \mathrm{Wu} \mathrm{H}$, et al. Inhibition of autophagy enhances the anticancer activity of silver nanoparticles. Autophagy. 2014;10(11): 2006-2020.

29. Gurunathan S, Han JW, Park JH, et al. Reduced graphene oxide-silver nanoparticle nanocomposite: a potential anticancer nanotherapy. Int $J$ Nanomedicine. 2015;10:6257-6276.

30. Gurunathan S, Kim E, Han JW, Park JH, Kim JH. Green chemistry approach for synthesis of effective anticancer palladium nanoparticles. Molecules. 2015;20(12):22476-22498.

31. Kovacs D, Migliano E, Muscardin L, et al. The role of Wnt/ $\beta$-catenin signaling pathway in melanoma epithelial-to-mesenchymal-like switching: evidences from patients-derived cell lines. Oncotarget. 2016;7(28): 43295-43314.

32. Gurunathan S, Han JW, Eppakayala V, Kim JH. Green synthesis of graphene and its cytotoxic effects in human breast cancer cells. Int $J$ Nanomedicine. 2013;8:1015-1027.
33. Jo E, Park SJ, Choi YS, Jeon WK, Kim BC. Kaempferol suppresses transforming growth factor- $\beta 1$-induced epithelial-to-mesenchymal transition and migration of A549 lung cancer cells by inhibiting Akt1mediated phosphorylation of Smad3 at Threonine-179. Neoplasia. 2015; 17(7):525-537.

34. Gurunathan S, Han JW, Kim ES, Park JH, Kim JH. Reduction of graphene oxide by resveratrol: a novel and simple biological method for the synthesis of an effective anticancer nanotherapeutic molecule. Int J Nanomedicine. 2015;10:2951-2969.

35. Gurunathan S, Jeong JK, Han JW, Zhang XF, Park JH, Kim JH. Multidimensional effects of biologically synthesized silver nanoparticles in Helicobacter pylori, Helicobacter felis, and human lung (L132) and lung carcinom a A549 cells. Nanoscale Res Lett. 2015; 10:35.

36. Shukla SP, Roy M, Mukherjee P, et al. Size selective green synthesis of silver and gold nanoparticles: enhanced antibacterial efficacy of resveratrol capped silver sol. J Nanosci Nanotechnol. 2016;16(3): 2453-2463.

37. Gnanajobitha G, Paulkumar K, Vanaja M, et al. Fruit-mediated synthesis of silver nanoparticles using Vitis vinifera and evaluation of their antimicrobial efficacy. J Nanostruct Chem. 2013;3:67.

38. Gurunathan S, Han JW, Eppakayala V, Jeyaraj M, Kim JH. An environmentally friendly approach to the reduction of graphene oxide by Escherichia fergusoni. J Nanosci Nanotechnol. 2013;13(3): 2091-2098.

39. Sathiya CK, Akilandeswari S. Fabrication and characterization of silver nanoparticles using Delonix elata leaf broth. Spectrochim Acta A Mol Biomol Spectrosc. 2014;128:337-341.

40. Jiang PH, Motoo Y, Sawabu N, Minamoto T. Effect of gemcitabine on the expression of apoptosis-related genes in human pancreatic cancer cells. World J Gastroenterol. 2006;12(10):1597-1602.

41. Celano M, Calvagno MG, Bulotta S, et al. Cytotoxic effects of gemcitabine-loaded liposomes in human anaplastic thyroid carcinoma cells. BMC Cancer. 2004;4:63.

42. Wei WT, Chen H, Wang ZH, et al. Enhanced antitumor efficacy of gemcitabine by evodiamine on pancreatic cancer via regulating PI3K/ Akt pathway. Int J Biol Sci. 2012;8(1):1-14.

43. Zhang W, Liang Z, Li J. Inhibition of rhotekin exhibits antitumor effects in lung cancer cells. Oncol Rep. 2016;35(5):2529-2534.

44. Bergman AM, Ruiz van Haperen VW, Kuiper CM, Peters GJ. Synergistic interaction between cisplatin and gemcitabine in vitro. Clin Cancer Res. 1996;2(3):521-530.

45. van Moorsel CJ, Pinedo HM, Veerman G, et al. Mechanisms of synergism between cisplatin and gemcitabine in ovarian and non-small-cell lung cancer cell lines. Br J Cancer. 1999;80(7):981-990.

46. Kim TH, Kim M, Park HS, Shin US, Gong MS, Kim HW. Size-dependent cellular toxicity of silver nanoparticles. J Biomed Mater Res A. 2012; 100(4):1033-1043.

47. Sriram MI, Kalishwaralal K, Gurunathan S. Biosynthesis of silver and gold nanoparticles using Bacillus licheniformis. Methods Mol Biol. 2012;906:33-43.

48. Gliga AR, Skoglund S, Wallinder IO, Fadeel B, Karlsson HL. Sizedependent cytotoxicity of silver nanoparticles in human lung cells: the role of cellular uptake, agglomeration and $\mathrm{Ag}$ release. Part Fibre Toxicol. 2014;11:11.

49. Jeong YJ, Kang JS, Lee SI, et al. Breast cancer cells evade paclitaxelinduced cell death by developing resistance to dasatinib. Oncol Lett. 2016;12(3):2153-2158.

50. Zhang GN, Liang Y, Zhou LJ, et al. Combination of salinomycin and gemcitabine eliminates pancreatic cancer cells. Cancer Lett. 2011; 313(2):137-144

51. Cao K, Yang J, Lin C, et al. Noxa enhances the cytotoxic effect of gemcitabine in human ovarian cancer cells. Cancer Biother Radiopharm. 2012;27(4):259-266.

52. Caltová K, Cervinka M. Antiproliferative effects of selected chemotherapeutics in human ovarian cancer cell line A2780. Acta Medica (Hradec Kralove). 2012;55(3):116-124. 
53. Liu A, Chen H, Tong H, et al. Emodin potentiates the antitumor effects of gemcitabine in pancreatic cancer cells via inhibition of nuclear factor-кB. Mol Med Rep. 2011;4(2):221-227.

54. Yong-Xian G, Xiao-Huan L, Fan Z, Guo-Fang T. Gemcitabine inhibits proliferation and induces apoptosis in human pancreatic cancer PANC-1 cells. J Cancer Res Ther. 2016;12:1-4.

55. Zhang XF, Shen W, Gurunathan S. Biologically Synthesized Gold Nanoparticles Ameliorate Cold and Heat Stress-Induced Oxidative Stress in Escherichia coli. Molecules. 2016;21(6). pii: E731.

56. Uchide N, Ohyama K, Bessho T, Yuan B, Yamakawa T. Apoptosis in cultured human fetal membrane cells infected with influenza virus. Biol Pharm Bull. 2002;25(1):109-114.

57. Uchide N, Tadera C, Sarai H, et al. Characterization of monocyte differentiation-inducing (MDI) factors derived from human fetal membrane chorion cells undergoing apoptosis after influenza virus infection. Int J Biochem Cell Biol. 2006;38(11):1926-1938.

58. Gómez-Lechón MJ, O’Connor E, Castell JV, Jover R. Sensitive markers used to identify compounds that trigger apoptosis in cultured hepatocytes. Toxicol Sci. 2002;65(2):299-308.

59. Vaux DL, Korsmeyer SJ. Cell death in development. Cell. 1999;96(2): 245-254.

60. Han B, Park D, Li R, et al. Small-Molecule Bcl2 BH4 Antagonist for Lung Cancer Therapy. Cancer Cell. 2015;27(6):852-863.

61. Zhang XF, Choi YJ, Han JW, et al. Differential nanoreprotoxicity of silver nanoparticles in male somatic cells and spermatogonial stem cells. Int J Nanomedicine. 2015;10:1335-1357.

62. Donadelli M, Dando I, Zaniboni T, et al. Gemcitabine/cannabinoid combination triggers autophagy in pancreatic cancer cells through a ROS-mediated mechanism. Cell Death Dis. 2011;2:e152.

63. Uzuki S, Fujita N, Hosogane N, et al. Excessive reactive oxygen species are therapeutic targets for intervertebral disc degeneration. Arthritis Res Ther. 2015;17:316.

64. Morin D, Assaly R, Paradis S, Berdeaux A. Inhibition of mitochondrial membrane permeability as a putative pharmacological target for cardioprotection. Curr Med Chem. 2009;16(33):4382-4398.

65. Seol JW, Chaudhari AA, Lee YJ, et al. Regulation of DR-5 protein and mitochondrial transmembrane potential by gemcitabine, a possible mechanism of gemcitabine-enhanced TRAIL-induced apoptosis. Oncol Rep. 2007;18(3):523-529.

66. Kovács D, Igaz N, Keskeny C, et al. Silver nanoparticles defeat p53positive and p53-negative osteosarcoma cells by triggering mitochondrial stress and apoptosis. Sci Rep. 2016;6:27902.
67. Maehara S, Tanaka M, Shimada K, Shirabe Y, Saito K, Takahashi Y. Selenoprotein $\mathrm{P}$, as a predictor for evaluating gemcitabine resistance in human pancreatic cancer cells. Int J Cancer. 2004;112(2):184-189.

68. Hill R, Rabb M, Madureira PA, et al. Gemcitabine-mediated tumour regression and p53-dependent gene expression: implications for colon and pancreatic cancer therapy. Cell Death Dis. 2013;4:e791.

69. Zhang R, Shi H, Ren F, et al. Knockdown of MACC1 expression increases cisplatin sensitivity in cisplatin-resistant epithelial ovarian cancer cells. Oncol Rep. 2016;35(4):2466-2472.

70. Leu JI, Dumont P, Hafey M, Murphy ME, George DL. Mitochondrial p53 activates Bak and causes disruption of a Bak-Mcl1 complex. Nat Cell Biol. 2004;6(5):443-450.

71. Gross A, Yin XM, Wang K, et al. Caspase cleaved BID targets mitochondria and is required for cytochrome c release, while BCL-XL prevents this release but not tumor necrosis factor-R1/Fas death. $J$ Biol Chem. 1999;274(2):1156-1163.

72. Johnstone RW. Deamidation of Bcl-X(L): a new twist in a genotoxic murder mystery. Mol Cell. 2002;10(4):695-697.

73. Qi F, Li A, Inagaki Y, et al. Induction of apoptosis by cinobufacini preparation through mitochondria- and Fas-mediated caspase-dependent pathways in human hepatocellular carcinoma cells. Food Chem Toxicol. 2012;50(2):295-302.

74. Galluzzi L, Kepp O, Kroemer G. Caspase-3 and prostaglandins signal for tumor regrowth in cancer therapy. Oncogene. 2012;31(23): 2805-2808.

75. Lawrence TS, Davis MA, Hough A, Rehemtulla A. The role of apoptosis in $2^{\prime}, 2^{\prime}$-difluoro-2'-deoxycytidine (gemcitabine)-mediated radiosensitization. Clin Cancer Res. 2001;7(2):314-319.

76. Fesus L, Davies PJ, Piacentini M. Apoptosis: molecular mechanisms in programmed cell. Eur J Cell Biol. 1991;56(2):170-177.

77. Huang P, Plunkett W. Induction of apoptosis by gemcitabine. Semin Oncol. 1995;22(4 Suppl 11):19-25.

78. Ren Q, Kao V, Grem JL. Cytotoxicity and DNA fragmentation associated with sequential gemcitabine and 5-fluoro-2'-deoxyuridine in HT-29 colon cancer cells. Clin Cancer Res. 1998;4(11):2811-2818.

79. Giovannetti E, Mey V, Nannizzi S, et al. Cellular and pharmacogenetics foundation of synergistic interaction of pemetrexed and gemcitabine in human non-small-cell lung cancer cells. Mol Pharmacol. 2005;68(1): 110-118.

80. Wang Y, Xiong X, Guo H, et al. ZnPP reduces autophagy and induces apoptosis, thus aggravating liver ischemia/reperfusion injury in vitro. Int J Mol Med. 2014;34(6):1555-15564.
International Journal of Nanomedicine

\section{Publish your work in this journal}

The International Journal of Nanomedicine is an international, peerreviewed journal focusing on the application of nanotechnology in diagnostics, therapeutics, and drug delivery systems throughout the biomedical field. This journal is indexed on PubMed Central, MedLine, CAS, SciSearch ${ }^{\circledR}$, Current Contents ${ }^{\circledR} /$ Clinical Medicine,
Dovepress

Journal Citation Reports/Science Edition, EMBase, Scopus and the Elsevier Bibliographic databases. The manuscript management system is completely online and includes a very quick and fair peer-review system, which is all easy to use. Visit http://www.dovepress.com/ testimonials.php to read real quotes from published authors. 